\title{
Research on Pre-service English Teachers' Professional Ability Development Preference Based on MALL*
}

\author{
Junshui Li \\ School of Foreign Languages, Chongqing Normal University, Chongqing, China \\ Miaomiao Gao \\ School of Foreign Languages, Chongqing Normal University, Chongqing, China \\ Xifang Tu \\ School of Foreign Languages, Chongqing Normal University, Chongqing, China
}

\begin{abstract}
Mobile-Assisted Language Learning (MALL) provides a new method and view for pre-service English teachers to improve their professional ability. Through the questionnaire survey of 105 students majoring in English in colleges and universities, using SPSS20.0 to carry out descriptive statistics on the effective data collected, analyzing the data of their maximum value, mean value and single sample $t$ test, this paper discusses the preference of different pre-service English teachers to improve their different professional abilities by using mobile devices. It is found that pre-service English teachers pay more attention to the improvement of English professional knowledge with the support of mobile devices, followed by teaching skills, and the lowest attention to the use of mobile devices to improve their teacher professional quality. Therefore, the purpose of this study is to find out the lack of pre-service English teachers' preference to improve their ability through mobile technology, which provides a new learning idea and inspiration for the future English teachers to polish their own professional skills.
\end{abstract}

Index Terms-MALL, pre-service English teacher, professional ability

\section{INTRODUCTION}

The way of education under the background of Internet Plus has changed greatly, and mobile learning has emerged with its preference. There is no definite concept of mobile learning. Integrating the views of domestic and foreign scholars (Clark Quinn, 2011; Chabra \& Figueiredo, 2001; Paul Harris, 2001; Cui Guangzuo, 2001; Ye Chenglin et al., 2004; Chen Zhenzhen, 2019), we can regard it as a new form of learning to access educational information, educational resources, educational services by using wireless mobile communication network technology and wireless mobile communication devices (smart phones, Ipad, smart watches, etc.). It benefits both students and teachers. The teachers of the 21st century grew up with the development of modern information technology. They are immersed in the digital educational environment and have a basic understanding of information technology. They deeply understand the close relationship between information technology and education, which has led to great changes in thinking, cognition, learning attitudes and habits among the new generation of teachers. Pre-service English teachers, in their professional pre-service training stage, play the dual status of the final stage of their students' career and the initial stage of teachers' entry. They are more proficient in the use of information technology, especially mobile devices such as smart phones and tablets, to assist learning. However, the different using preference affects their professional development to some extent and Ajzen (1991: 192) has put forward the theory of planned behavior, pointing out that the will of the individual will directly affect the behavior of the individual, and other factors take the intention of behavior as the medium to influence the actual behavior. Therefore, this study tries to analyze their preference to improve their professional ability development in the following three aspects: professional knowledge, professional skills and professional quality, referred from the Iceberg Model (McClelland, 1973; Spencer \& Spencer, 1993; Zhong Weihe, Wang Weiwei, 2016). Through the investigation of the use of mobile devices by pre-service English teachers in universities, the study aims to put forward targeted professional development suggestions for pre-service English teachers.

In recent years, Studies of Mobile-Assisted Language Learning (MALL) have been heated topic (Comac, 2008; Kukulasa, 2009; Golonka, 2014; Jiang Yinjian, 2016; Lisso, etc, 2016; Zhang Chunyan, 2018; Lexie, 2019). But only few scholars pay attention to the professional development of pre-service teachers supported by mobile devices. Abroad university such as Kinston and Sheffield Hallam University applied SMS (Simple Message Service) to the practice of

${ }^{*}$ Project: Supported by Postgraduate Research Innovation Project in Chongqing 
education and teaching, and proved that it is effective to improve professional development through experiments. The Frohberg and Schwabe (2009) of Helge New University have also applied short message service to the training of pre-service teachers and obtained positive experimental results, which further proves the effectiveness of mobile learning in language. In China, the study of foreign language teaching models based on mobile learning terminals has been written by Lu Yingbo and Yang Ping (2013). They put forward constructive ideas for the development of mobile language learning based on the constructivism teaching theory and created a new direction for pre-service English teachers to develop their professional abilities from the following dimensions: Mobile Learning Pattern Design, Mobile Language Learning Content Design, Mobile Learning Foreign Language Teaching Pattern Architecture. Yu Lingyan (2014) constructed a mobile and interactive virtual learning environment for the professional development of pre-service teachers by setting up a mobile learning system. Under this system, the biggest characteristic and advantage of teachers' mobile learning is to realize the sharing of resources and the convenience of communication. Although the system still has some problems in hardware equipment and resource integration, it is a good strategy for professional development of pre-service teachers. Li Gang et al .(2019) found that through the investigation and statistics of the six important abilities of the 2015 students who majored in English teaching of Hunan University of Arts and Sciences in their educational practice, they generally use mobile learning in teaching design and teaching practice to improve and develop their professional ability. The research also points out that under the background of Internet Plus, the professional development of pre-service teachers assisted by mobile technology is bound to be effective.

\section{ICEBERG MODEL}

In 1973, American psychologist McClellan proposed the Iceberg Model, which divides the different forms of individual quality into Above Iceberg and Below Iceberg. After that, American scholars Lyle Spencer and Signe Spencer(1993) put forward the Quality Iceberg Model. The Quality Iceberg Model vividly describes the individual quality as an iceberg floating on the ocean surface, in which knowledge and skills belong to the surface part exposed to the water surface, which is also called the benchmark quality. Internal drive, social motivation, personality, self-image, attitude and so on belong to the deep part hidden in the water, this part is called discriminative quality. This model is widely used in the evaluation of human ability development. In 2016, Zhong Weihe and Wang Weiwei combined the National Standard of English Teachers to construct the Iceberg Model of the professional development structure of pre-service English teachers (seen in Figure 1): the professional knowledge and professional skills above the surface of the iceberg are the external representation of teachers' ability, and the professional skills are the application of professional knowledge. The professional quality of the part below the surface of the iceberg is the core of the development of teachers' professional ability and plays an overall role in the performance of professional knowledge and skills.

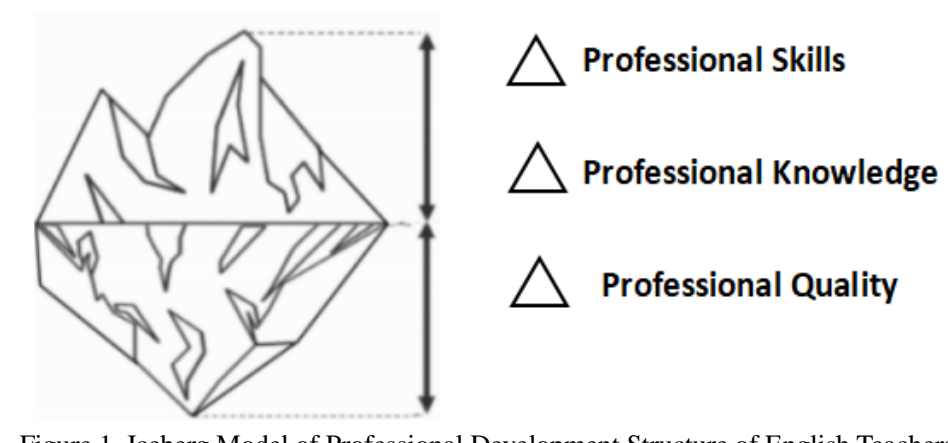

Figure 1. Iceberg Model of Professional Development Structure of English Teachers

\section{A. Professional Knowledge}

In addition to language and culture knowledge, professional knowledge, second language acquisition theory knowledge and education theory knowledge, English teachers should also have knowledge of classroom organization, evaluation and supervision, educational technology, industry development and so on. In other words, English teachers only have a solid basic language skills is not enough, but also need to continue to learn new teaching methods including information technology knowledge, so as to understand the learning effect and progress of students, communicate with each other in a timely and multi-channel way, organically combine language knowledge and language use, so as to create a learning environment suitable for students' needs and promote students' understanding of English. The cognition of language and culture can cultivate students' global vision, values and other humanistic qualities.

In terms of language culture and subject knowledge, English teachers should pay attention to both the instrumental and humanistic nature of the English language. Through foreign language teaching, students can not only use English as a tool to study, work and communicate, but also as a bridge to broaden their international cultural horizon and enhance the humanistic spiritual quality. This requires that the knowledge structure of teachers should not only include the pure language level and relevant knowledge of foreign language subjects, but also emphasize the integration and 
interconnection of language and culture based on the concept of "language diversity". According to the viewpoint of "linguistic diversity", every language learning and every experience of learning a language promotes the construction of communicative competence. Based on this idea, English teaching is not a single, independent language teaching activity, but to initiate the interrelation and interaction of multiple languages.

In terms of relevant knowledge of educational theory, professional development of English teachers includes language acquisition theory, pedagogical knowledge and other contents. The "National standard" also proposes that English teachers should master pedagogy, foreign language teaching and learning and other relevant theoretical knowledge, so as to effectively carry out classroom teaching, assessment, student learning stage tracking and other teaching activities, and master students' needs and learning development rules.

\section{B. Professional Skills}

Professional skills directly reflect the professional development level of teachers.

First, teaching instruction ability. Teachers can design teaching procedure and organize class according to the requirements of teaching quality, and integrate teaching standards into teaching planning, design and teaching practice. For example, foreign language teachers should be able to carry out teaching design according to curriculum standards, combined with the cultural characteristics of target language and students' actual situation. Second, teaching strategy ability. Teachers can understand and use different teaching strategies to help English learners develop comprehensive language ability and cultivate their language and cultural literacy and critical thinking ability. Foreign language teachers should fully understand foreign language learning strategies to help learners master and develop specific strategies and methods such as time management, progress monitoring and learning assessment. In addition, new teachers should master and apply a variety of teaching strategies to help learners improve their language skills, understand the target language culture, and develop critical thinking skills. Third, technology application ability, under the background of the Internet era, the wide application of multimedia and network technology has led to the reform of English teaching mode. Therefore, in addition to using modern educational technology to carry out classroom teaching, English teachers should also use multiple Internet resources to guide students to learn independently. Of course, teaching should avoid excessive dependence on information technology, because information technology itself has its limitations, and clear teaching objectives and teaching design is the basis of teaching. Fourth, teaching reflection and reform ability. Teaching reflection is the key factor of teachers' development. English teachers should have the ability of teaching reflection, constantly examine teaching and learning in teaching practice, actively adjust teaching strategies, and carry out teaching reform according to the actual situation and students' needs. Teachers can record, evaluate and improve teaching by means of teaching log, observation and listening. Fifthly, teaching and scientific research ability. The role of English teacher in the new era has changed from teacher to researcher. The combination of scientific research and teaching is helpful for teachers to find and solve problems consciously in teaching practice, which promotes the development of students and teachers' self-development. For example, as an important way of teaching and research, action research can help foreign language teachers reduce intuitive teaching behavior and find a theoretical framework to solve problems through practical exploration. The sixth point is practical ability. In English major, translation major and English Teaching major belong to practical major. Taking English Teaching majors as an example ,"National Standard" requires teachers to master international knowledge and cultures, ELF teaching theory, pedagogical knowledge. Therefore, English teachers need more experience and practical skills. Lastly, assessment and Test Ability. This ability requirement is not only suitable for English teachers to adopt reasonable and effective evaluation methods to improve teaching quality for different types of courses and teaching objectives, but also for English teachers to achieve professional development through self-evaluation in all stages. Therefore, foreign language teachers should adopt multiple evaluation methods, such as evaluating students' foreign language communication ability through communicative activities, and adjusting teaching according to evaluation results. Besides, tracking teaching effect and diagnosing students' learning progress through formative evaluation are also significant to make an excellent assessment.

\section{Professional Quality}

Professional quality is an indispensable part of the professional standard of English teachers, which mainly refers to the ideological beliefs and ways that teachers should possess in their work. Ethic devotion, personality and other value orientation and self-professional development pursuit are included.

First of all, teachers should fulfill the relevant obligations and abide by professional ethics. English teachers should be able to understand the main significance of language cultures in the context of globalization and help students to establish correct values. Secondly, teachers should establish the concept of lifelong development, through on-the-job further education, teaching practice and other ways to continuously improve the subject knowledge literacy and comprehensive professional skills and teaching cooperative ability. Third, teachers should carry out their own professional development and enhance their comprehensive ability. At the same time, they should carry out extensive cooperation and communication with other advanced teachers to enhance their professional influence, and make positive contributions to the construction of education in his own field.

\section{RESEARCH DESIGN}




\section{A. Research Problems}

What is the preference of pre-service English teachers to use mobile devices to improve their professional ability?

\section{B. Research Object}

In this study, 105 (male 15, female 90) English normal major students in a university were taken as the research objects. These students had received systematic training in normal education during their academic study, including basic foreign language skills, foreign language teaching skills, micro-teaching, educational practice and educational technology training. Among the pre-service English teachers surveyed, $83.33 \%$ had educational practice or teaching experience.

\section{Research Methods and Tools}

This study adopts the questionnaire method and data analysis method, and takes the Questionnaire on Mobile Learning Tendency of Pre-service English Teachers as the research tool. This questionnaire focuses on the three dimensions of professional knowledge, professional skills and professional quality. The questionnaire used Likert scale to set "very consistent", "consistent", "relatively consistent", "not consistent", "very inconsistent" five kinds of answers for each question, and some questions were calculated by digital visualization.

\section{Data Collection and Analysis}

First of all, the researchers distributed 105 electronic questionnaires on WeChat and QQ platforms, and collected 105 valid questionnaires, with the recovery efficiency of $100 \%$. First, the answers from three different dimensions were recorded as 5, 4, 3, 2, and 1, and the total score of each respondent was the sum of his answers to each question.

Then, the researcher calculated the mean value and standard deviation of the following three dimensions of professional ability through SPSS20.0, which were most worthy of the macro tendency of pre-service English teachers to use mobile devices to improve their professional competence.

Finally, the researchers counted the mean values of the contents in each dimension, conducted a one-sample T-test, and conducted significance analysis. Through significance analysis, the researchers found that the statistical results were significant. Through mean value analysis, the tendency of specific content under three dimensions is obtained.

\section{E. Reliability and Validity Verification}

To test the structural validity of the scale, principal component analysis and maximum variation (Varimax) were used to analyze the validity of the questionnaire, and the suitability of the sample was indicated by factor analysis (KMO $=0.83,2=1039.944, \mathrm{P}<.001)$. Cronbach's coefficient measured by the scale was 0.886 , indicating high validity and reliability of the questionnaire, which could be used for measurement.

\section{DATA ANALYSIS AND RESUlt DISCUSSION}

\section{Data Analysis}

The following table shows the variable of preference of different pre-service English teachers to improve their professional competence through descriptive statistical analysis. It presents the maximum value, mean value and standard deviation of the three dimensions (see Table 1). In terms of the overall distribution, the maximum value of professional knowledge is slightly higher than that of teaching skills and professional quality, and it is evenly distributed around the value 4, among which the average value of professional knowledge is the highest $(\mathrm{M}=4.242)$. Thus, it can be seen that pre-service foreign language teachers tend to improve their ability in professional knowledge when using mobile devices, while they pay the least attention to professional quality.

TABLE 1.

Dimension ANALYSIS OF PROFESSIONAL COMPETENCE PREFERENCE

\begin{tabular}{|c|c|c|c|c|c|}
\hline Categories & Sample size & minimum value & $\begin{array}{c}\text { Maximum } \\
\text { value }\end{array}$ & Means & $\begin{array}{c}\text { Standard } \\
\text { deviation }\end{array}$ \\
\hline Professional knowledge & 105 & 1.000 & 4.800 & 4.242 & 0.584 \\
\hline $\begin{array}{c}\text { Professional } \\
\text { skills }\end{array}$ & 105 & 1.000 & 4.300 & 4.081 & 0.660 \\
\hline Professional quality & 105 & 1.000 & 3.900 & 3.824 & 0.585 \\
\hline
\end{tabular}

1. Micro preference analysis of professional knowledge

Zhong Weihe, Wang Weiwei (2016) based on the iceberg model framework construct English teachers' professional ability. Professional knowledge survey content is mainly divided into the following four categories: subject knowledge, culture and discipline knowledge, second language acquisition theory, pedagogical knowledge, and for each type of the contents of the single sample t test, it can be concluded as the following data: 
TABLE 2.

MEANS OF PROFESSIONAL KNOWLEDGE PREFERENCE AND SINGLE-SAMPLE T TEST

\begin{tabular}{|c|c|c|c|c|}
\hline $\begin{array}{l}\text { Professional } \\
\text { knowledge }\end{array}$ & Contents & Means & $\mathbf{t}$ & $\mathbf{p}$ \\
\hline \multirow{6}{*}{ subject knowledge } & Use mobile devices to improve your English listening ability & 4. 231 & 17.997 & $0.000 * *$ \\
\hline & Read English on your mobile device & 4. 367 & 19.743 & $0.000 * *$ \\
\hline & Use mobile devices to improve your spoken English & 4. 013 & 2.062 & $0.000 * *$ \\
\hline & Use mobile devices to learn English writing skills & 3. 631 & -7.450 & $0.000 * *$ \\
\hline & Use mobile devices to expand English vocabulary & 4. 667 & 27.166 & $0.000 * *$ \\
\hline & Use mobile devices to learn English grammar & 3. 931 & -3.011 & $0.000 * *$ \\
\hline $\begin{array}{l}\text { Language and } \\
\text { cultural knowledge }\end{array}$ & $\begin{array}{l}\text { Actively use mobile devices to learn relevant language and } \\
\text { cultural knowledge }\end{array}$ & 3. 763 & -6.112 & $0.000 * *$ \\
\hline Pedagogical theory & Pedagogical, psychological theories through mobile devices & 3. 483 & -13.067 & $0.000 * *$ \\
\hline SLA theory & $\begin{array}{l}\text { Use mobile devices to consult and learn relevant theoretical } \\
\text { knowledge of SLA }\end{array}$ & 3. 793 & -1.153 & $0.000 * *$ \\
\hline
\end{tabular}

Note: $* *$ indicates significant correlation at 0.01 level (double-tailed)

As can be seen from Table 2, $\mathrm{P}<0.01$ indicates that the statistical results are of high significance. The distribution of the mean values of each category is 3.5-4.5 and the overall mean value is 4.242, indicating that pre-service English teachers are highly inclined to improve their professional knowledge by using mobile technology. After analyzing the specific aspects of pre-service English teachers improving their professional knowledge with mobile technology, it is found that the mean value of pre-service English teachers learning subject knowledge with mobile devices is 4.14, which is higher than the other three micro dimensions. Among them, the mean value of "improving their own knowledge related to pedagogical theory with mobile devices" is the lowest. Therefore, it indicates that pre-service English teachers are more inclined to improve their subject knowledge when they use mobile devices to improve their professional knowledge.

2. Micro-orientation analysis of professional skills

The contents of the pre-service English teachers' professional skills mainly consist of the following categories: teaching strategy ability, teaching design and implementation ability, application of modern educational technology ability, teaching reflection and reform ability, teaching and scientific research ability, practical ability, evaluation and testing ability. The specific analysis is shown in Table 3 .

TABLE 3.

MEANS OF PRofessional SKILLS PREFERENCE AND Single-SAMPLE T TEST

\begin{tabular}{|c|c|c|c|c|}
\hline $\begin{array}{c}\text { Professional } \\
\text { skills }\end{array}$ & Contents & Means & $\mathbf{t}$ & $\mathbf{p}$ \\
\hline $\begin{array}{l}\text { Teaching strategy } \\
\text { ability }\end{array}$ & Monitor your learning process using mobile devices & 4.022 & 2.298 & $0.000 * *$ \\
\hline $\begin{array}{l}\text { Teaching Instruction } \\
\text { ability } \\
\end{array}$ & Design Software Resources for Mobile Learning & 3.214 & -19.494 & $0.000 * *$ \\
\hline $\begin{array}{c}\text { Technology application } \\
\text { ability }\end{array}$ & Improve technical literacy in education & 3.969 & -2.744 & $0.000 * *$ \\
\hline $\begin{array}{c}\text { Teaching reflection and } \\
\text { reform ability }\end{array}$ & $\begin{array}{l}\text { Create personal e-file/reflective blog/memorandum, } \\
\text { upload records, photos, videos }\end{array}$ & 4.500 & 25.332 & $0.000 * *$ \\
\hline $\begin{array}{l}\text { Teaching and scientific } \\
\text { research ability }\end{array}$ & $\begin{array}{l}\text { Improve your research capabilities through mobile } \\
\text { technology }\end{array}$ & 4.441 & 24.139 & $0.000 * *$ \\
\hline \multirow{3}{*}{ Practical ability } & $\begin{array}{l}\text { Use mobile technology to assist teaching in } \\
\text { educational practice }\end{array}$ & 4.011 & 1.477 & $0.000 * *$ \\
\hline & $\begin{array}{l}\text { Guide students to learn autonomously by using } \\
\text { mobile devices }\end{array}$ & 4.265 & 18.003 & $0.000^{* *}$ \\
\hline & Use mobile technology to assist teaching in future & 3.750 & -4.245 & $0.000^{* * *}$ \\
\hline $\begin{array}{l}\text { Assessment and test } \\
\text { ability }\end{array}$ & $\begin{array}{l}\text { Use mobile technology to conduct Non-paper } \\
\text { testing }\end{array}$ & 4.559 & 25.635 & $0.000^{* *}$ \\
\hline
\end{tabular}

As can be seen from Table 3, $\mathrm{P}<0.01$ shows that the statistical results are significant, and the overall average value is 4.081, which indicates that pre-service English teachers have a certain tendency to improve their professional skills by using mobile technology. Among them, teaching and scientific research ability, teaching reflection and reform ability, assessment and testing ability tend to be higher, teaching design and implementation ability, modern educational technology application ability, practical confidence in the future are lower. Most respondents agreed that mobile technology-assisted assessment tests were more likely to be non-paper tests organized using mobile technology mobile technology and considered that this approach was not only time-saving, but can be more timely and quickly to reflect the learning level of the subjects, and help to improve their ability to evaluate and test. However, they do not agree that mobile technology design software resources can improve their teaching design and implementation ability, and think that the current English teaching design form has been diversified enough, like PPT, which combines video, audio, pictures and text that can also meet the needs of students in the process of foreign language learning. 
3. Micro tendency analysis of professional quality

Table 1 shows that in the use of mobile devices, compared with professional knowledge and teaching skills, pre-service English teachers have a lower tendency to improve their professional quality, with an average of 3.824 . According to the division, professional quality has three micro dimensions: professional ethics and norms, lifelong learning and professional development, and professional community. The numerical analysis of the corresponding questionnaire is shown in Table 4.

TABLE 4

MEANS OF PROFESSIONAL QuALITY PREFERENCE AND Single-SAMPLE T TEST

\begin{tabular}{|c|c|c|c|c|}
\hline Professional quality & Contents & Means & $\mathbf{t}$ & $\mathbf{p}$ \\
\hline Professional ethics & $\begin{array}{l}\text { Improve teachers' professional ethics through mobile } \\
\text { devices }\end{array}$ & 3.876 & -3.634 & $0.000 * *$ \\
\hline \multirow{2}{*}{$\begin{array}{c}\text { Lifelong learning } \\
\text { and } \\
\text { professional } \\
\text { development }\end{array}$} & Mobile devices will contribute to lifelong learning & 4.333 & 21.459 & $0.000 * *$ \\
\hline & $\begin{array}{l}\text { Learn interdisciplinary knowledge by using mobile } \\
\text { devices }\end{array}$ & 3.667 & -7.833 & $0.000 * *$ \\
\hline \multirow[t]{2}{*}{$\begin{array}{l}\text { Professional } \\
\text { community }\end{array}$} & $\begin{array}{c}\text { Join the teacher learning team cooperation and } \\
\text { communication through mobile device to achieve } \\
\text { resource sharing }\end{array}$ & 4.012 & 1.478 & $0.000^{* *}$ \\
\hline & $\begin{array}{c}\text { Focus on and discuss educational heats } \\
\text { mobile devices }\end{array}$ & 3.232 & -19.433 & $0.000 * *$ \\
\hline
\end{tabular}

Note: $* *$ indicates significant correlation at 0.01 level (double-tailed)

Table 4 shows that in the mean value and the sample $\mathrm{t}$ of professional quality tendency, the mean value of lifelong learning and professional development is the highest $(\mathrm{M}=4.000)$, while the average value of professional community is only 3.622. This shows that in professional quality, people tend to use mobile devices to improve their lifelong learning and professional development ability. At the same time, pay attention to educational hot spots through mobile devices, participate in discussion, the lowest average of all dimensions, indicating that pre-service English teachers tend to pay less attention to the use of mobile devices and discuss educational heats, which may be due to the low frequency of the presentation about educational heats in the form of mobile devices.

\section{CONCLUSION}

Through the data statistics and analysis, it can be found that pre-service English teachers tend to develop professional knowledge ability than professional skills and professional qualities when using mobile devices to assist learning. At the micro level, it also has its own emphasis, especially in the use of mobile devices to expand English vocabulary, pre-service teachers have the highest tendency. Therefore, pre-service English teachers should pay attention to several aspects when using mobile technology to improve their professional ability:

(1) Use the mobile technology rationally and balance the development of professional competences. The diversity of mobile phone applications is destined to provide more options for pre-service teachers. No matter the word learning applications such as word chopping "," scallop word ",or other listening and speaking applications, like TED speech , BBC News English or other applications like Sina Weibo, Baidu Tieba, by which we can participate in educational hot discussion. They all provide a variety of platform options for teachers' professional ability. However, many pre-service English teachers tend to give priority to the application of improving professional knowledge when using a series of APP, and often ignore the existence of APP in improving professional quality. Therefore, teachers should carefully choose mobile device applications, not only focus on their development, but also pay attention to the neglected aspects.

(2) Improve information technology literacy, and focus on both of the internet and mobile. To some extent, mobile technology can improve the professional ability of pre-service English teachers, but teachers should also know that mobile technology online learning is not the only channel, or even an important channel. Teachers should fully mobilize the positive aspects of online learning and adopt all effective means to improve their own information technology literacy so as to be able to develop their own professional ability in combination with multiple online learning methods.

(3) Assist language teaching effectively and improve the quality of education and teaching. The professional development of pre-service teachers supported by mobile technology, whose direct benefit group is teachers, indirect benefit group is students. In the process of using mobile technology to learn, pre-service teachers should fully explore and understand the advantages and disadvantages of mobile learning, learn from each other and integrate applications in order to make more efficient use of English teaching and help students develop better.

In a word, the development of pre-service English teachers is bound to be related to the development of students in the future. Only on the premise of correctly making good use of the application of mobile technology and reasonably treating the tendency of professional development under mobile assistance, can teachers' own professional ability be improved as a whole, thus contributing to the education and teaching in the future to a certain extent. 


\section{REFERENCES}

[1] Ajzen, I. (1991). The theory of planned behavior. Organizational Behavior and Human Decision Processes, 50, $179-211$.

[2] Chen, C. M., \&Chung, C. J. (2008). Personalized mobile English vocabulary learning system based on item response theory and learning memory cycle. Computers \& Education, 51,624-645.

[3] Clark N. Quinn. (2010). The Mobile Academy: M learning For Higher Education. San Francisco, California, Jossey-Bass Press.

[4] Comac, L. (2008). Using audioblogs to assist English-language learning: an investigation into student perception. Computer Assisted Language Learning, 21,181- 198.

[5] Council of Europe. (2001). Common European Framework of Reference for Languages: Learning, Teaching, Assessment. Cambridge: Cambridge University Press.

[6] Chen Zhenzhen. (2019). A Study on the Learning Input of Smartphone Assisted Foreign Language Teaching in Classroom Teaching. Audio-visual Teaching of Foreign languages 6, 49-54.

[7] Cui Guangzuo et al. (2001). Mobile Education - a New Direction of Modern Educational Technology National Higher Education Technical Cooperation Committee. Theory and Practice - e-Learning Research and Application of Modern Educational Technology. Chongqing, southwest normal University Press.

[8] Frohberg \&C. Göth \& G. Schwabe. (2009). Mobile Learning projects-a critical analysis of the state of the art. Journal of Computer Assisted Learning, 25,307-331.

[9] Golonka, E. M., Bowles, A. R., Frank, V. M., Richardson, D. L. \& Freynik, S. (2012). Technologies for foreign language learning: A review of technology types and their effectiveness. Computer Assisted Language Learning, 27, 70-105.

[10] Kukulska-Hulme. (2009). Will mobile learning change language learning? ReCALL, 21, 157-165.

[11] Li Gang, Fan Lina, Li Jinshu. (2019). A Study on the Development of Pre-service Professional Competence for Middle School Teachers. Internet Journal of Educational Science, Hunan normal University, 01,102-107.

[12] Lu Yingbo, Yu Ping. (2013). A Study on the Mode of Foreign Language Teaching Based on Mobile Learning Terminal. Modern Educational Technology, 6, 71-75.

[13] McClelland D C. (1973). Testing for competence rather than for "intelligence". American Psychologist,28, 1-14.

[14] Paul Harris:Goin Mobile[EB/OL], http:// www.learning circuits. org/2001/ jul2001/ harris.html (accessed 5/6/2020).

[15] Spencer LM\& Spencer S M. (2001). Competence at Work: Models for Superior Performance. New York: Wiley.

[16] Yu Lingyan. (2014). A Study on the Mobile Learning Strategy of Teachers in Colleges and Universities with the Integration of "Threes and One Bo Value" .Engineering, 29, 241-244.

[17] Zhong Weihe, Wang Weiwei. (2016). Construction of Competence Composition and Development System for English Teachers in China under the Background of "National Standards " Foreign Languages, 6, 2-8.

Junshui Li was born in Fujian, China in 1995. He is currently a postgraduate student in the School of Foreign Languages, Chongqing Normal University, Chongqing, China. His research interests include Cognitive linguistic and Mobile-Assisted language learning.

Mr. Li is a member of the Postgraduate Research Innovation Project in Chongqing.

Miaomiao Gao was born in Shanxi, China in 1996. She is currently a postgraduate student in the School of Foreign Languages, Chongqing Normal University, Chongqing, China. Her research interests include English education and text book analysis.

Ms. Gao is a member of the Postgraduate Research Innovation Project in Chongqing.

Xifang Tu was born in Jiangxi, China in 1996. She is currently a postgraduate student in the School of Foreign Languages, Chongqing Normal University, Chongqing, China. Her research interests include English education and second language acquisition.

Ms. Tu is a member of the Postgraduate Research Innovation Project in Chongqing. 